\title{
KONFLIK SUNNI-SYIAH DI TIMUR TENGAH PERSPEKTIF GEOPOLITIK DAN DAMPAKNYA TERHADAP HUBUNGAN SUNNI-SYIAH DI INDONESIA
}

\author{
Humaini ${ }^{1,2}$ \\ ${ }^{1}$ Interdisciplinary Islamic Studies Konsentrasi Kajian Timur Tengah \\ Universitas Islam Negeri Sunan Kalijaga Jogyakarta \\ 2Email: humaini.hd@gmail.com
}

\begin{abstract}
Since the Iranian Islamic Revolution in 1979, Sunni sentiments with Shia have been redistributed everywhere. Even though the Sunni-Shia sentiment is not the main source of conflict but political geography, which is related to borders and natural resources. Because, the Middle East is located in a strategic area so that it becomes a very important region in the global political map. Conflicts that are inseparable from Sunni-Shia sentiments in the Middle East include: Shiite Sunni conflict in the Gulf War, attacks on the commemoration of Ashura (Karbala Massacre), Shiite Sunni conflicts in Syria and Lebanon, and Shia Sunni conflicts in the Yemeni Civil War. This conflict has a huge impact on Shia Sunni relations in Indonesia. The impact of the conflict was the occurrence of Sunni Shia conflict in Indonesia, which included: the attack on the Shia Islamic Boarding School, the dissolution of the commemoration of the Ashura tradition, the dissolution of the anniversary of Fatimah Az-Zahra, the ban on the Rausyan Fikr Foundation in Yogyakarta, and the attack on the Shia community in Madura. This paper attempts to examine the impact of the Shia Sunni conflict from a Geopolitical perspective and the impact of the conflict on Sunni- Shia relations in Indonesia.
\end{abstract}

Keywords: Conflict, Shia-Sunni, Middle East, and Geopolitics

$$
\begin{aligned}
& \text { ملخص } \\
& \text { منذ قيام الثورة الإيرانية عام 1979، نشرت عاطفيات النزاع بين السنة والشيعة في مناطق كثيرة فن العالم. في الحقيقة } \\
& \text { أن العامل الحقيقي فن اندلاع الصراع بين السنة والشيعة هو العامل الجغرافي السياسي المتعلق بالولايات الحدودية }
\end{aligned}
$$

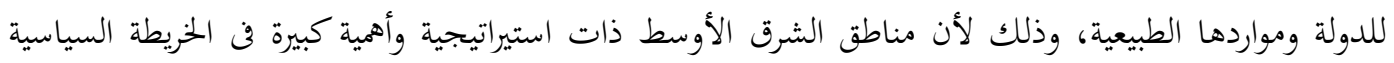

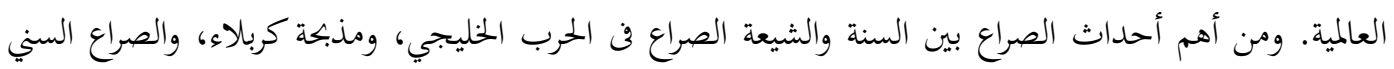

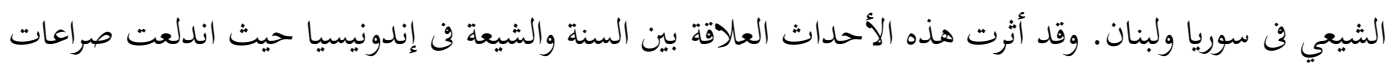

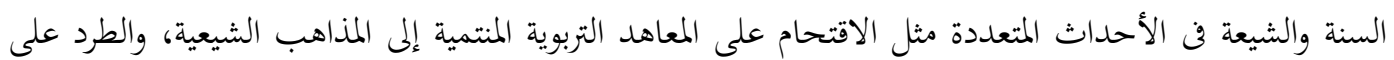

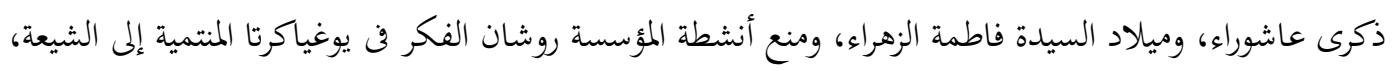

$$
\begin{aligned}
& \text { والهجوم على بعض الشيعيين فن مادورا. هذه المقالة تبحث فن آثار الصراع بين السنة والشيعة من المنظور الجغرافي } \\
& \text { السياسي و تأثراتما على علاقة السنة والشيعة في إندونيسيا. } \\
& \text { الكلمات المفتاحية: صراع السنة والشيعة، الشرق الأوسط، الجغرافيا السيياسية. }
\end{aligned}
$$




\section{A. Pendahuluan}

Konflik antara Syiah dengan Sunni yang mewarnai perkembangan politik Timur Tengah dewasa ini bukanlah sesuatu yang muncul secara tiba-tiba. Konflik antara keduanya memiliki akar sejarah yang panjang bahkan benih-benih konflik itu sudah ada semenjak paska era Nabi Muhammad Saw. Menurut Sahide, konflik ini dimulai dari suksesi kepemimpinan setelah meninggalnya Nabi Saw. Pengangkatan Abu Bakar menjadi pengganti Nabi Saw. menjadi awal mula konflik ini terjadi, dan memunculkan fraksi pengikut setia Ali ibn Abi Thalib dan fraksi yang melegitimasi kepemimpinan Abu Bakar (Sahide, 2013:315).

Pada era modern, sejak Revolusi Islam Iran pada tahun 1979, sebagai wujud kebangkitan Syiah, sentimen-sentimen peledak konflik Sunni-Syiah disebarkan kembali di mana-mana sehingga poros politik Islam terbelah menjadi dua poros: poros Arab Saudi (yang kebetulan mayoritas Sunni) dan poros Iran-Suriah (yang kebetulan dipimpin oleh Syiah), dengan menjadikan berbagai negara di kawasan Timur-Tengah sebagai ladang persengketaannya, misalnya: Lebanon, Irak, Suriah, Yaman, dan seterusnya (Shah, 2015:137-138).

Memanasnya suhu politik di berbagai kawasan di Timur Tengah tersebut berdampak dalam mengobarkan perang ideologis Sunni-Syiah di berbagai belahan lain dunia Islam, khususnya yang sangat terasa di tanah air Indonesia. Berdasarkan uraian ini, penulis melakukan kajian terkait konflik Sunni-Syiah yang terjadi di Timur Tengah dilihat dari perspektif Geopolitik serta dampak konflik tersebut terhadap hubungan Sunni-Syiah di Indonesia.

\section{B. Landasan Teori}

Geopolitik Timur Tengah adalah sebuah studi tentang pengaruh faktorfaktor geografi dan demografi negaranegara di kawasan Timur Tengah dalam peran dan tujuan politik untuk memperjuangkan kepentingannya terhadap dunia internasional, begitupun sebaliknya, yaitu hubungan kepentingan dunia internasional terhadap kawasan Timur Tengah (Anderson, 2000:23). Dengan kata lain, kajian geopolitik Timur Tengah berarti kajian hubungan internasional kawasan ini dari sudut pandang unsurunsur yang berkaitan pada keadaan alam maupun tata kehidupan yang melingkupinya.

Geopolitik awalnya muncul pada rentang abad ke-19 dan abad ke-20 yang diinisiasi oleh pemikiran Fredrich Ratzel (1844-1904) yang mengatakan bahwa setiap Negara memiliki suatu konsep ruang dan kontrol terhadap suatu wilayah. Istilah geopolitik semula oleh pencetusnya, Frederich Ratzel (1944-1904), diartikan sebagai ilmu bumi politik (Political Geography). Istilah geopolitik dikembangkan dan diperluas lebih lanjut oleh Rudolf Kjellen (1864-1922) dan Karl Haushofer (1869-1946) menjadi Geographical Politic (Gyorgy, 1944: ]152).

\section{Pembahasan}

\section{Peta Konflik Timur Tengah Perspektif Geopolitik}

Kawasan Timur Tengah merupakan tempat lahirnya persaingan dan konflik kepentingan negara-negara kawasan dan negara-negara Barat. Ekspedisi militer Napoleon Bonaparte ke Mesir pada bulan Juli tahun 1798 menjadi titik awal ekspansi Barat ke Timur Tengah pada zaman modern. Keberhasilan Napoleon telah membuka mata dunia bahwa Kekaisaran Turki Utsmani telah melemah dan hal tersebut menjadikan semangat kolonial Eropa untuk memecah belah kawasan Timur Tengah yang selama ini di bawah kekuasaan kekaisaran ini (Shaleh, 2001: 34).

Pasca Perang Dunia I (1914-1918)

Inggris dan Prancis sepakat untuk berbagi pengaruh di Timur Tengah. Kesepakatan tersebut dirumuskan dalam Perjanjian Sykes-Picot atau The 1916 Asia-Minor Agreement pada 16 Mei 1916. Sebutan Perjanjian Sykes-Picot merujuk pada delegasi kedua negara, Sir Marks Sykes dan Francois Georges-Picot. Perjanjian Inggris-Prancis ini membahas soal pembagian wilayah bekas Kekaisaran 
Turki Utsmani menjadi dua protektorat atau negara jajahan.

Perjanjian tersebut diperkuat dalam Konferensi San Remo. Hasil konferensi tersebut sangat menguntungkan bagi Inggris dan Prancis, baik dari segi militer, politik, maupun ekonomi. Konferensi tersebut memutuskan, Inggris menjadi pemegang mandat di Palestina dan Mesopotamia (Yordania dan Irak), sedangkan Prancis di Suriah dan Lebanon. Selain peranan Inggris dan Prancis, keruntuhan Kekaisaran Turki Utsmani dan tumbuhnya paham nasionalisme merupakan katalisator yang mendorong negara-negara Timur Tengah untuk memperjuangkan kemerdekaan mereka (Armstrong, 2007: 171-173).

Pasca Perang Dunia II, konflik di Timur Tengah mengalami babak baru. Hal tersebut ditandai dengan menguatnya dominasi politik dan ekonomi negaranegara industri besar serta perebutan pengaruh antara Amerika Serikat dan Uni Soviet (Long and Reich, 1980: 9). Minyak juga yang membuat negara-negara Timur Tengah menjadi kaya raya, karena cadangan minyak bumi di Timur Tengah mencapai $60 \%$ dari cadangan minyak dunia (Indriana, 2017: 17).

Selain minyak, tidak sedikit konflik yang terjadi di kawasan Timur Tengah disebabkan oleh keterbatasan air tawar. Urusan air tawar sebagai kebutuhan hidup sehari-hari tergolong sensitif dalam peta perpolitikan di kawasan ini. Laporan yang dirilis oleh PBB pada tahun 2003 menyatakan bahwa urusan air ini mengakibatkan 21 manuver militer dalam beberapa dekade terakhir (As-Sirjani, 2015: 292).

\section{Konflik Sunni Syiah di Timur Tengah Perspektif Geopolitik}

Sebenarnya, isu perbedaan politis yang memecah kaum muslimin ke dalam dua kelompok Sunni dan Syiah bisa terhitung kadaluarsa. Akan tetapi sepanjang sejarah Islam pra-modern hingga saat ini, fenomena perpecahan masa lalu ini terus menerus dihidupkan kembali. Maka pada masa kini perpecahan tersebut dihidupkan kembali di mana-mana semenjak revolusi Iran tahun

1979 dicetuskan (Shah, 2015: 136-137).

\section{a. Konflik Sunni Syiah dalam Perang} Teluk

Perang Teluk Irak-Iran 1980-1988 tidak terlepas dari sentimen SunniSyiah. Negara-negara Sunni, dengan alasan takut dengan ekspansi Syi'ah Imam Khomeini, berada di belakang Saddam Hussein. Di satu sisi, Iran didukung oleh negara-negara dan kelompok-kelompok pemimpin Syi'ah, seperti Suriah, Hizbullah, gerakan Hamas, dan beberapa gerakan perlawanan di negara-negara lain (Sahide, 2013: 321).

Namun apabila ditelusuri sentimen Sunni-Syiah bukanlah sumber utama konflik Iran dan Irak melainkan faktor geografi politik kedua negara, yaitu berkaitan dengan perbatasan, sumber daya alam berupa minyak dan air. Posisi laut Irak hanya berada di sebelah tenggara yang sangat sempit, yaitu dari garis pantai di Umm Qashr di Teluk Persia. Irak hanya memiliki akses laut sepanjang $19 \mathrm{~km}$, Irak mengalami kesulitan mengekspor minyak melalui laut (Indriana, 2017: 17).

Keterbatasan akses laut tersebut menyebabkan Irak menjadi agresif serta berambisi menguasai "Shattal-Arab", tempat bertemunya sungai Eufrat dan Tigris sepanjang $80 \mathrm{~km}$ suatu daerah vital bagi kedua belah pihak sebagai akses minyak ke Teluk, sehingga menimbulkan konflik antara Irak dan Iran, pada tahun 1975, Irak-Iran sepakat untuk menandatangani Perjanjian Aljiers yang membelah "Shatt al-Arab" bagi pelayaran Irak dan Iran, dengan imbalan Iran tidak akan menghasut atau membantu pemberontakan Suku Kurdi di Irak. Akan tetapi, perjanjian ini kemudian dicabut secara sepihak oleh Irak karena peristiwa "Revolusi Islam" di Iran. Saddam menuding adanya upaya pemerintah revolusioner Islam Iran untuk menghasut mayoritas Syiah Irak untuk melakukan pemberontakan terhadap pemerintahannya. Akibatnya, 
kedua negara ini terlibat perang selama 8 tahun (Indriana, 2017: 17).

b. Penyerangan terhadap Peringatan Hari Asyura (Karbala Massacre)

Pada tanggal 4 Maret 2004 yang bertepatan dengan 10 Muharam 1425 H. dilaksanakan peringatan Asyura pertama sejak jatuhnya rezim Ba'ath. Selama puluhan tahun, orang Syiah yang mayoritas di Irak tidak diperkenankan memperingati hari keagamaan. Maka tidak mengherankan, pada hari itu begitu banyak orang Syiah yang datang untuk memperingati syahidnya Imam Husain (Rakhmat, 2015: 68-69).

Pembantaian Karbala yang terjadi pada pagi hari merekonstruksi pembantaian keluarga Nabi di Karbala, 14 abad sebelumnya. Mereka berlarian di tengah-tengah asap, reruntuhan, pecahan kaca dan logam, serta potongan-potongan tubuh menuju 'atabah muqaddasah, bangunanbangunan berkubah emas. Al-Qaidah mengaku bertanggung jawab terhadap penyerangan yang lebih dikenal sebagai "Karbala Massacre" (Rakhmat, 2015: 68-69).

\section{c. Konflik Sunni Syiah di Suriah dan} Lebanon

Hubungan Arab Saudi dan Iran sudah sejak dulu memiliki masalah besar, baik secara politik, strategis, maupun ideologis (Syi'ah dan Sunni). Pasca the Arab Spring, keduanya berebut pengaruh serta supremasi di Timur Tengah dan Teluk. Pada krisis Suriah sangatlah jelas: Iran mendukung rezim Bashar al-Assad yang Syi'ah, sedangkan Arab Saudi mendukung kelompok oposisi yang mayoritas Sunni. Presiden Suriah, Bashar alAssad, berasal dari kelompok Syi'ah yang minoritas, sementara kelompok yang mayoritas, yaitu Sunni, terpinggirkan (Sahide, 2013: 320).

Pada konflik Suriah, ada pertarungan antara Amerika Serikat dan sekutunya yang mayoritas negara Sunni dengan China dan Rusia dan sekutunya yang mayoritas negara Syiah. Assad adalah salah satu sekutu terkuat Presiden Rusia, Vladimir Putin di Timur Tengah. Rusia mengubah jalannya perang dengan membantu membangun militer Suriah modern dan melakukan intervensi militer pada tahun 2015. Selain Rusia, salah satu sekutu kunci Assad adalah Iran. Jadi, ketika Assad terancam, Iran akan melangkah untuk mendukungnya. Begitu pula dengan Hizbullah, partai politik dan milisi Lebanon yang merupakan sekutu Teheran (Tribunnews Aceh, 2018).

Perserikatan Bangsa-Bangsa (PBB) sebagai badan dunia selalu gagal dalam mengupayakan penyelesaian konflik di Suriah. Hal ini karena adanya ketidaksepahaman di antara sesama anggota PBB. Amerika Serikat, Uni Eropa, Arab Saudi, Qatar, dan lain-lain (Rini, 2017).

Meskipun Rusia dan China tidak menghendaki intervensi asing dalam penyelesaian konflik Suriah, tetapi sesungguhnya mereka juga melakukan intervensi tersebut. Intervensi ini dilakukan untuk mempertahankan kepentingan mereka. Rusia ingin melindungi kepemilikan pelabuhan di Tartus yang merupakan satu-satunya di Timur Tengah. Selain itu, Suriah merupakan salah satu konsumen terbesar persenjataan Rusia.

Konflik yang terjadi di Suriah berdampak pada Lebanon, Pemerintah Lebanon terbelah menjadi dua faksi; faksi anti Suriah dan faksi pro Suriah. Kelompok pertama adalah aliansi politisi Sunni, Kristen dan Druze (sebuah sekte agama Islam) dan mendapat dukungan dari Amerika Serikat. Kelompok kedua adalah gabungan kekuatan-kekuatan Syiah yang didominasi oleh Hizbullah, dengan dukungan dari Suriah dan Iran. (BBC, 2006).

Pertikaian paling buruk terjadi di Kota Tripoli, Lebanon. Saat itu tujuh warga muslim Sunni tewas dan 60 lainnya luka setelah berunjuk rasa menentang rezim Basyar al-Assad 
diakhiri bentrokan dengan pihak Syiah (Merdeka; Gara-gara Suriah, Sunni Syiah di Lebanon Memanas; https://www.merdeka.com/khas/garagara-suriah-syiah-sunni-di-Lebanonmemanas-konflik-sunni-syiah-3.html; diakses pada tanggal 29 Agustus 2019).

\section{d. Konflik Sunni Syiah pada Perang} Sipil Yaman

Pada tahun 2015, sebagaimana Suriah dan Lebanon, perang saudara Yaman terjadi antara dua pihak yang masing-masing mengklaim sebagai pemerintah Yaman. Pihak pertama mendukung pemerintahan Abd Rabbuh Mansur Hadi dan berbasis di Aden yang dilindungi oleh Arab Saudi, dan pihak yang lain mendukung pemerintah Komite Revolusi yang dibentuk oleh kelompok Houthi, gerakan Syiah yang memiliki hubungan dengan Iran dan beroposisi dengan Sunni dan didukung oleh mantan Presiden Ali Abdullah Saleh, yang sejak Januari 2015 menguasai ibu kota Sana'a (Indriana, 2017: 22).

Perang sipil Yaman dimulai pada 2014 ketika kelompok Houthi, mengambil alih ibu kota Yaman dan kota besar lain, Awal Maret 2015, koalisi negara-negara Teluk Arab yang dipimpin oleh Arab Saudi meluncurkan kampanye isolasi ekonomi dan serangan udara terhadap gerilyawan Houthi, dengan dukungan logistik dan intelijen AS. Setelah kampanye militer Koalisi Arab, Hadi membatalkan pengunduran dirinya dan kembali ke Aden pada September 2015, dan pertempuran berlanjut (Tempo; Kenapa Yaman Dilanda Perang; https://dunia.tempo.co/read/1142124/k enapa-yaman-dilanda-

perang?page_num $=2$; diakses pada tanggal 29 Agustus 2019).

Pada Juli 2016, dua kelompok yang bersekutu, yakni gerakan Houthi dan pemerintah mantan Presiden Ali Abdullah Saleh, yang digulingkan pada 2011 setelah hampir tiga puluh tahun berkuasa, mengumumkan pembentukan dewan politik untuk memerintah Sana'a dan sebagian besar Yaman utara.

Namun, pada Desember 2017, Saleh memutuskan hubungan dengan Houthi dan meminta para pengikutnya untuk mengangkat senjata untuk melawan Houthi. Saleh terbunuh dan pasukannya kalah dalam dua hari. Arab Saudi membentuk koalisi negaranegara Arab untuk mengalahkan Houthi di Yaman pada 2015. Koalisi Arab terdiri dari Kuwait, Uni Emirat Arab, Bahrain, Mesir, Maroko, Yordania, Sudan dan Senegal.

3. Dampak Konflik Timur Tengah terhadap Hubungan Sunni Syiah di Indonesia

Mayoritas penduduk Indonesia adalah Muslim dan mayoritas Muslim Indonesia adalah penganut Sunni, yang juga merupakan mayoritas penduduk Muslim di dunia. Akan tetapi, terdapat sejumlah kecil penganut Syiah yang hidup di tengah kaum mayoritas tersebut (Nasr, 2003: 78).

Syiah hanya menjadi mayoritas di Iran (sekitar 90\%), Irak (60\%) dan Bahrain (60\%). Sedangkan eksistensi Syiah di Indonesia, masih belum banyak diketahui. Meskipun beberapa penulis dan peneliti beranggapan bahwa Syiah sudah ada di wilayah Nusantara sejak awal kedatangan Islam dan pengaruhnya, hingga kini, cukup kuat dalam tradisi Islam di Nusantara (Sultriana dan Mustahyun, 2017: 102-103).

Pengaruh Syiah masih dapat terlihat dari beberapa tradisi masyarakat Muslim yang hingga kini masih dipertahankan. Ali Hasjmy menyatakan bahwa terdapat beberapa tradisi umat Islam di Indonesia yang dipengaruhi tradisi Syiah. Di antaranya tradisi Hoyak Tabuik atau perayaan Hoyak Hosen merupakan sebuah tradisi yang telah digelar sejak tahun 1829 di Pariaman, Sumatera Barat. Perayaan tersebut dilaksanakan setiap Muharram sebagai peringatan terhadap tragedi berdarah yang menimpa cucu Nabi Muhammad Saw, Sayyidina Husain. Tradisi memperingati peristiwa Karbala juga dilaksanakan setiap tahun di Bengkulu, dengan istilah Tabot atau Tabut 
dan dihelat sejak 1-10 Muharam. Adapula tradisi Kenduri yang sudah sangat familiar di lingkungan masyarakat Islam Nusantara, yang berarti tradisi makan-makan untuk memperingati Fatimah Az-Zahrah, putri Nabi Muhammad Saw. (Pojok Satu; 2018; Tradisi Syiah di Indonesia; https://pojoksatu.id/lipsus/2018/06/08/9 tradisi-syiah-indonesia-nomor-8-palingsering-kamu-kerjakan-lho/; diakses pada tanggal 5 September 2019). (Muwahidah, 2015: 190-191).

Perkembangan Syiah di Indonesia melahirkan kekhawatiran Rezim Soeharto, sehingga ada upaya pembatasan aktifitas gerakan Syiah. Hal tersebut dilandasi semangat Revolusi Islam di Iran dikhawatirkan dapat menjadi stimulan revolusi politik di Indonesia. jatuhnya Soeharto, kebebasan politik membuka kemungkinan bagi berbagai kelompok agama, termasuk Syiah, untuk mengekspresikan ideologi dan identitasnya secara bebas sekaligus keterbukaan mendebatkan beragam nilai (competing values).

Situasi politik yang lebih kondusif ini melatarbelakangi pembentukan dan kehadiran Ikatan Jama'ah Ahlul Bait Indonesia (IJABI) pada tahun 2000 dengan Jalaluddin Rahmat sebagai arsitek utamanya sebagai upaya untuk membangun rumah bersama dan mempersatukan komunitas Syiah di Indonesia. Posisi IJABI kemudian semakin kukuh setelah organisasi tersebut mendapatkan pengakuan legal formal dari pemerintah Indonesia pada 11 Agustus 2000 (Sultriana dan Mustahyun, 2017: 102-103).

Fenomena memburuknya hubungan Sunni dan Syiah di Indonesia merupakan dampak dari situasi geopolitik di antara bangsa-bangsa Arab di Timur Tengah. Konflik politik tersebut tidak hanya berdampak dalam sentimen Sunni Syiah di kawasan Timur Tengah, akan tetapi berdampak pula hingga ke berbagai belahan dunia Islam lainnya, salah satunya di Indonesia. Namun, fakta bahwa Assad yang menganut Alawi (aliran sempalan Syiah yang konsep teologinya sudah sangat berbeda dari Syiah Imamiyah) (Rais, 2015: 4).

Kontestasi kekuatan regional, yaitu Arab Saudi dan Iran, memainkan peran penting dalam membangun sentimen Sunni dan Syiah. Arab Saudi adalah negara yang sudah sejak awal resmi memfatwakan Syi'ah sebagai aliran yang sesat. Di Arab Saudi, aliran Syi'ah tidak mendapatkan toleransi sedikitpun. Lebih dari itu, pemerintah Saudi sudah menyatakan bahwa aliran Syi' ah terlarang di negaranya. Oleh karena itu, hubungan Iran, yang mayoritas Syi'ah, dengan Arab Saudi tidak pernah harmonis (Sahide, 2013: 322).

Pertarungan Iran dan Arab Saudi mendapatkan momentum dalam kasus Suriah. Iran dengan sepenuh hati dan totalitas berdiri di belakang Bashar alAssad, presiden yang berasal dari kelompok Syi'ah. Sementara Arab Saudi berada di belakang kelompok oposisi yang terus berupaya menggulingkan rezim Syi'ah yang berkuasa di Suriah (Rais, 2015: 5). Sentimen Sunni-Syiah yang kembali diangkat dapat menjadi polemik umat Islam secara global serta dapat mengancam keberagamaan dan harmonisasi, khususnya umat Islam di Indonesia (Al-Mandari, 2015: 185).

Sentimen anti Syiah kian masif setelah Majelis Ulama Indonesia (MUI) memformulasikan kriteria kelompokkelompok sesat pada tahun 2005. Tuduhan kelompok sesat pertama kali ditujukan kepada Ahmadiyah. Tetapi kelompok antisyiah mulai mendesak bahwa paham Syiah juga harus dimasukkan ke dalam kategori kelompok sesat. Modus operandi yang sama juga terjadi di Pakistan dimana Sipah-e-Sahaba (Pembela Sahabat) juga mempromosikan isu yang sama, setelah berhasil mengkafirkan Ahmadiyah, mereka mendesak pengkafiran Syiah. (Muwahidah, 2015: 191).

Selain disebabkan, salah satunya, fatwa Majelis Ulama Indonesia (MUI) Surabaya yang menyebutkan bahwa ajaran Syi'ah adalah sesat. Secara umum, peristiwa konflik Sunni Syiah selama ini di berbagai daerah di Indonesia juga disebabkan oleh UU No. 1/PNPS/1965 
sering dipahami dan ditafsirkan tanpa memperhatikan secara serius asas kebebasan berkeyakinan dan beragama, sebagaimana dijamin oleh konstitusi (Sultriana dan Mustahyun, 2017: 106).

Kampanye anti Syiah di media sosial mengalami peningkatan selepas tahun 2013. Menurut BBC Indonesia, pada tahun 2011-2012 jumlah tagar \#antiSyiah hanya puluhan dan bertambah menjadi ratusan pada 2013. Pada tahun 2015 (Januari-Oktober) bertambah secara signifikan, $B B C$ Indonesia mencatat penggunaan tagar \#antiSyiah sudah lebih dari 39.000 kali. Sementara kata 'Syiah' dikicaukan lebih dari 530.000 kali (Rais, 2015: 4).

Pada tanggal 20 April 2014 M. gerakan anti Syiah semakin menunjukkan eksistensinya dengan dideklarasikannya sebuah organisasi yang bernama Aliansi Nasional Anti Syiah (ANNAS). Deklarasi yang diselenggarakan di Masjid Al-Fajr, Jl. Cijagra, Buah-Batu Bandung Jawa Barat tersebut dihadiri oleh 99 Ulama, Habaib, Pimpinan Ormas Islam, Pimpinan Pondok Pesantren dari berbagai daerah di Tanah Air, juga dihadiri oleh Asda III Gubernur Jawa Barat DR. H. Ahmad Hadadi, yang mewakili Gubernur Jawa Barat menyatakan dukungan sepenuhnya Pemda Jabar terhadap Deklarasi berdirinya Aliansi Nasional Anti Syiah (ANNAS). Deklarasi diakhiri dengan pembacaan Naskah Deklarasi oleh Ketua ANNAS K.H. Athian Ali Moh., Lc., MA (Annas Indonesia; Iftitah dan Sejarah Aliansi Nasional Anti Syiah;

http://www.annasindonesia.com/profil/iftit ah-dan-sejarah-aliansi nasional-anti-syiah; diakses pada tanggal 10 September 2019).

Deklarasi tersebut berisi: Pertama, Menjadikan lembaga, "Aliansi Nasional Anti Syiah" sebagai wadah dakwah amar ma'ruf nahi munkar; Kedua, Memaksimalkan upaya preventif, antisipatif, dan proaktif membela dan melindungi ummat, dari berbagai upaya penyesatan akidah dan syari'ah yang dilakukan oleh kelompok syiah di Indonesia; Ketiga, Menjalin Ukhuwah Islamiyah dengan berbagai organisasi dan gerakan dakwah di Indonesia, untuk mewaspadai, menghambat dan mencegah pengembangan ajaran sesat syiah; Keempat, Mendesak Pemerintah agar segera melarang penyebaran faham dan ajaran syiah, serta mencabut izin seluruh organisasi, yayasan, dan lembaga yang terkait dengan ajaran syiah di seluruh Indonesia.

\section{Konflik Sunni Syiah di Indonesia \\ a. Penyerangan terhadap Pondok Pesantren Berhaluan Syiah}

Pondok Pesantren Al-Hadi di pekalongan yang dipimpin oleh Ahmad Baraqbah dan Thoha Musawa merupakan satu-satunya ponpes yang dikelola dengan sistem pendidikan ala Hawza Ilmiyah di Qom Iraq. Ponpes AlHadi Pekalongan didirikan pada tahun 1409 H / 1988 M beralamat di Jl. Agung Salim, Gang 5 no. 4 Rt. 1 Rw. 3 Kelurahan Klego, Kota Pekalongan Jawa Tengah. Lokasinya terletak di Tengah kota di wilayah yang dikenal dengan kampung Arab dengan luas lahan sekitar 1,5 hektar (Putra, Ahmad Roni Adi; Memandang Perspektif Gerakan Revolusi Syiah; https://www.kompasiana.com/ahmadro niadiputra8149/5bb34694677ffb78844 e7597/memandang-perspektif-gerakanrevolusi-syi-ah; diakses pada tanggal 15 September 2019).

Pada tahun 1998 Ponpes AlHadi mendirikan cabang di lahan seluas $6.500 \mathrm{~m} 2$ terletak di desa Brokoh, Kecamatan Wonotunggal, Kabupaten Batang, Jawa Tengah. Cabang itu dikhususkan untuk santri putra, sementara santri putri tetap di Pekalongan. Biaya pembangunan Ponpes Al-Hadi baik di Pekalongan dan Batang itu diperoleh dari luar negeri, yaitu Iran, Lebanon, dan komunitas Syi'ah lainnya di Arab Saudi dan Bahrain (1998-2000).

Protes yang dilakukan warga dilakukan dengan aksi pembakaran Pondok Pesantren Al-Hadi di desa Brokoh, Wonotunggal, Kabupaten Batang. Insiden ini mengakibatkan 3 rumah hancur, 1 mobil rusak, dan satu 
gudang material dibakar. Ini merupakan insiden pertama konflik kekerasan terhadap komunitas Syi'ah. Peritiwa ini terjadi pada tanggal 14 April 2000. Pada 20 April 2007, organisasi massa Islam (Persis, Muhammadiyah, dan Nahdhatul Ulama) yang menamakan dirinya HAMAS berjumlah 2000 orang, dipimpin oleh Habib Umar Assegaf berencana akan mendatangi Pesantren YAPI Bangil, Jawa Timur (Baharun, 2013: 62).

Pada 15 Februari 2011, ratusan orang tidak dikenal menyerang Pondok Pesantren Yayasan Pendidikan Islam (Yapi) di Desa Kenep, Kecamatan Beji, Kabupaten Pasuruan, Jawa Timur. Massa ada yang berpakaian putih dan bersorban dan ada juga yang memakai rompi hitam. Serangan massa itu mengakibatkan empat santri terluka di bagian kepala (Tribun News; 2011; Inilah Kronologi Penyerangan Pondok Pesantren Yapi; https://www.tribunnews.com/regional/ 2011/02/15/inilah-kronologis-

penyerangan-pondok-pesantren-yapi; diakses pada tanggal 15 September 2019).

Peristiwa itu berawal ketika puluhan santri asyik bermain bola di halaman pesantren, tiba di depan pagar massa langsung melempari santri dan melukai dua sekuriti pesantren yang berjaga di pos satpam. Kemudian, mereka masuk ke halaman pesantren dan menyerang santri yang ada di dalam. Mereka kembali lagi dari arah Pandaan dan melintas di depan Pondok Pesantren Yapi, aksi pelemparan sempat terjadi. Saat terjadi ketegangan itulah, tiga orang dari kelompok massa itu jatuh dari motor. Polisi yang berada di lokasi kejadian langsung mengamankan mereka dan membawanya ke Polres Pasuruan untuk diperiksa (Tribun News; 2011; Inilah Kronologi Penyerangan Pondok Pesantren Yapi; https://www.tribunnews.com/regional/ 2011/02/15/inilah-kronologispenyerangan-pondok-pesantren-yapi; diakses pada tanggal 15 September 2019).

Pada tahun 2013, konflik antara warga Sunni dengan Syiah terjadi di Puger Kulon, Kecamatan Puger, Jember Selatan. Pihak pondok pesantren Darus Sholihin mengajukan izin ke kepolisian mengadakan karnaval HUT -RI, meski lewat bulan Agustus. Namun Polres Jember tidak mengeluarkan izin untuk mengadakan kegiatan (Kecamatan Puger) telah melarang pihak Yayasan Ponpes Darus Sholihin mengadakan acara di luar pondok. Sebab, pihak warga Sunni di Puger berkeberatan dengan kegiatan Pondok yang telah menyebarkan ajaran Syiah (Kiblat; 2013; Kronologi Bentrok Umat Islam Jember Vs Syiah; https://www.kiblat.net/2013/09/13/kro nologi-bentrok-umat-islam-jember-vssyiah/; diakses pada tanggal 20 September 2019).

Pada 11 September 2013, Pihak Ponpes dengan jumlah puluhan orang memaksakan untuk mengadakan karnaval HUT RI. Warga mengetahui pihak ponpes menjebol barikade dan tidak menghiraukan aparat tersulut emosinya dan mendatangi pondok pesantren Darus Sholihin. Ada 5 motor yang dirusak, tiga di antaranya dibakar. Masjid ponpes pun jadi sasaran warga, beduk dan mimbar tempat imam berceramah dirusak. Sebanyak 13 rumah warga, 1 buah ruko, 1 kostorit (tempat penyimpanan ikan), 1 buah truk dihancurkan massa Syiah yang diperkirakan berjumlah ratusan (Okezone; 2013; Bentrok Warga dengan Penganut Syiah; https://news.okezone.com/read/2013/0 9/11/521/864633/bentrok-wargadengan-penganut-syiah-satu-orangtewas; diakses pada tanggal 20 September 2019).

b. Pembubaran terhadap Peringatan Tradisi Asyura

Pada 13 Januari 2008, sekitar pukul 20:00 WIT, kurang lebih 200 orang melakukan pembubaran kegiatan kelompok Syi'ah di Yayasan Al-Qurba 
yang dimotori oleh Hasyim Umar di Dusun Kebun Ruek, Kecamatan Ampenan, Lombok Barat NTB dalam rangka memperingati hari Asyura (Baharun, 2013: 62).

Pada tanggal 23 Nopember 2012, Sekitar seratus anggota Front Pembela Islam (FPI) Sulawesi Selatan mencoba membubarkan peringatan Asyura yang diselenggarakan Ikatan Jamaah Ahlul Bait Indonesia (IJABI) di gedung Graha Pena, di Jalan Urip Sumoharjo, Makassar, untuk memperingati gugurnya cucu Nabi Muhammad, Imam Husein bin Ali yang tewas di Karbala pada 10 Muharram pada abad pertama tahun hijriyah. Aksi massa FPI tersebut berhasil dihalau anggota Polsek Panakukang dan Satuan Brimob Polda Sulsel yang bersenjata lengkap. Sempat terjadi insiden saling lempar antara massa FPI dan kelompok Syiah, namun berhasil diredam oleh aparat. (AnNajah; FPI Makasar Bubarkan Peringatan Asyura; https://www.annajah.net/fpi-makasar-bubarkanperingatan-asyura-yang-dihadirijalaludin-rahmat/; diakses pada tanggal 26 September 2019).

Pada tahun 2013, peringatan tradisi Asyura selama berabad-abad selalu diadakan setiap 10 Muharam di beberapa kota di Indonesia, antara lain di Jakarta, Makassar, Surabaya dan Bandung mengalami beberapa hambatan. Di Jakarta dibubarkan paksa pada akhir acara, di Makassar diserbu dengan kelompok bersenjata tajam hingga terjadi bentrokan saat upaya pembubaran acara oleh sekelompok warga. Sementara di Bandung, polisi menolak memberikan izin penyelenggaraan di Istana Kana dan memindahkannya ke lokasi yang lebih sempit, sehingga polisi dianggap berpihak pada intoleransi dan bukannya menjamin kebebasan melaksanakan ibadah (BBC; 2013; Forum Syiah; https://www.bbc.com/indonesia/forum/ 2013/11/131115_forum_syiah; diakses pada tanggal 26 September 2019).
Pada tanggal 20 September 2018, sejumlah warga dan organisasi masyarakat (ormas) menolak dilaksanakannya peringatan Asyura oleh jamaah Syiah di Bandung. TNI berjaga-jaga di sekitar Majelis Habib Alwi Assegaf, Jalan Kembar VI, tempat acara digelar. Aksi menolak peringatan Asyura 2018 di Kota Bandung melahirkan beberapa kesepakatan, salah satunya jamaah Syiah di Bandung Raya tidak akan melaksanakan lagi acara serupa pada tahun-tahun berikutnya (Tirto; Penolakan Peringatan Asyura di Bandung; https://tirto.id/penolakan-peringatanasyura-di-bandung-c1SR; diakses pada tanggal 26 September 2019).

c. Pembubaran terhadap Peringatan Hari Lahir Fatimah Az-Zahra

Pada tanggal 01 April 2016, diselenggarakan sebuah acara untuk memperingati hari lahir Fatimah AzZahra. Acara tersebut diprakarsai oleh HMI Pekanbaru, Jaringan Aktifis Filsafat Islam (Jakfi) Pekanbaru, Batas Arus, dan Himpunan Mahasiswa Patani Pekanbaru. Tokoh yang diundang pada saat itu adalah AM Safwan merupakan Pengasuh Pondok Pesantren Mahasiswa Murtadha Muthahhari, Rausyan Fikr Yogyakarta.

Pada saat acara berlangsung, ratusan massa Ahlusunnah wal Jamaah (Aswaja) se-Pekanbaru yang menamakan dirinya Barisan Pemuda Islam Riau (BPI-R) bersama aparat kepolisian membatalkan acara peringatan kelahiran Fatimah Az-Zahra tersebut. AM Safwan akhirnya dibawa ke markas FPI Riau di Jalan Sungai Kampar, Pekanbaru (Kiblat; 2016; Acara Tokoh Syiah di Pekanbaru Dibubarkan Warga dan Aparat; https://www.kiblat.net/2016/04/02/acar a-tokoh-syiah-di-pekanbaru-

dibubarkan-warga-dan-aparat/; diakses pada tanggal 29 September 2019).

Pada tanggal yang sama, aksi peringatan hari kelahiran putri Nabi Muhammad SAW, Fatimah Azzahra di Pasuruan, Jawa Timur, dibubarkan 
ratusan orang yang mengatasnamakan diri ormas Aswaja. Parahnya, kordinator dari gerakkan ini adalah seorang Anggota DPRD Pasuruan. Sebelumnya, massa Aswaja terlebih dahulu berkumpul di Alun-Alun Bangil, dan bergerak ke tempat acara dengan berjalan kaki. Setelah tiba di lokasi, massa meneriakkan ujaran-ujaran kebencian, dan menyebarkan selebaran yang berisi seruan kekerasan, serta menuntut pengajian 'Wiladah Putri Nabi SAW Fatimah Azzahra' dibubarkan (Okezone; 2016; Kronologi Pembubaran Pengajian IWOC di Pasuruan;

https://news.okezone.com/read/2016/0 4/01/519/1351738/kronologipembubaran-pengajian-iwoc-dipasuruan; diakses pada tanggal 29 September 2019).

\section{d. Pelarangan terhadap Yayasan} Rausyan Fikr di Yogyakarta

Di Yogyakarta, yayasan Rausyan Fikr sudah berdiri sejak 1995 dan aktif dengan berbagai macam kegiatankegiatan keilmuan, seperti kajian pemikiran tokoh Syiah sekelas Murtadho Muthahari, Ali Syariati, dan filsuf Islam lainnya yang lahir dari tradisi Syiah. Kajian tersebut melibatkan banyak kaum terdidik, misalnya Dosen dan Mahasiswa, tetapi pada 21 November 2013, tersebar kabar yayasan Syi'ah tersebut diancam akan diserang oleh kelompok tertentu (Tempo; Kelompok Syiah di Yogya Diancam Diserang; https://nasional.tempo.co/read/531705/ kelompok-syiah-di-yogya-diancamdiserang; diakses pada tanggal 29 September 2019). Polisi memfasilitasi mediasi antara pihak massa dan pengelola Rausyan Fikr serta menjaga ketat lokasi untuk antisipasi gerakan yang anarkis (Tempo; Markas Syiah di Jalan Kaliurang Diserbu Massa; https://nasional.tempo.co/read/712442/ markas-syiah-di-jalan-kaliurangdiserbu-massamengapa/full\&view=ok; diakses pada tanggal 29 September 2019).
Tidak hanya penghentian kegiatan, papan nama Yayasan Rausyan Fikr juga terpaksa diturunkan demi keamanan, hal ini juga berdampak pada lingkungan sekitar Yayasan yang terprovokasi oleh hate speech yang melanda di sudutsudut Yogyakarta dengan tersebarnya berbagai poster tentang wacana kebencian kepada Syiah. Yayasan Rausyan Fikr mendapat jaminan keamanan dari Sultan HB $\mathrm{X}$ dan Kapolda DIY.

Pada akhirnya, pemerintah Yogyakarta mengadakan dialog terbuka dan mengundang berbagai ormas keagamaan untuk mengurai eksistensi Syiah di Yogyakarta. Namun dialog tersebut tidak memberikan solusi dan jalan keluar yang baik, dialog yang diadakan juga tidak menunjukan dialog yang sehat dan terbuka yang memuaskan berbagai pihak yang terlibat dalam masalah ini, yang pada akhirnya FJI mendorong MUI Yogyakarta mengeluarkan Fatwa pelarangan kegiatan Syiah di Yogyakarta. MUI Yogyakarta mengeluarkan Fatwa pelarangan kegiatan Syiah. Akibat dari fatwa MUI DIY terkait dengan pelarangan Syiah di Yogyakarta, hingga saat ini kelompok Syiah di Yogyakarta melakukan aktivitas keagamaan secara individu (Widyadara, 2015: 119).

Menurut Sahide pelarangan terhadap yayasan Rausyanfikir ini jika berdalih dengan alirannya yang dianggap sesat, tentulah sejak awal berdirinya sudah dilarang. Oleh karena itu, jika melihat dari segi momentumnya di mana wacana pendiskreditan ini masif tentulah tidak lepas dari prahara politik yang kini sedang menjadi tontonan menarik di Timur Tengah (Sahide, 2013: 322).

e. Penyerangan terhadap Warga Syiah di Madura

Pada bulan Oktober 2009, serangan serupa terhadap Jamaah Syiah sebenarnya sudah terjadi. Pada saat itu, 3.000-an orang sudah siap menyerang Nangkrenang. Ancaman serangan 
terjadi kembali pada 4 April 2011, ketika Jamaah Syiah hendak memperingati Maulid Nabi Muhammad SAW. Pada hari Kamis, 29 Desember 2011 terjadi aksi pembakaran rumah ketua Ikatan Jamaah Ahl al-Bait (IJABI), Ust Tajul Muluk, beserta dengan dua rumah Jamaah Syiah lainnya, serta Mushola yang digunakan sebagai sarana peribadatan. Aksi tersebut dilakukan oleh sekitar 500 orang yang mengklaim diri sebagai kelompok Sunni (Detik; Penyerangan Jamaah Syiah; https://news.detik.com/berita-jawatimur/d-1802832/penyerangan-jamaahsyiah-cmars-pemerintah-gagal-

melindungi-warganya; diakses pada tanggal 1 Oktober 2019).

Pada 26 Agustus 2012, terjadi konflik Sunni-Syiah di Sampang. Konflik tersebut merupakan klimaks dari konflik kelompok Islam Syiah dan Sunni yang disertai aksi kekerasan dan menyebabkan satu orang tewas. Bahkan Kapolsek Omben, AKP Aris menjadi korban dalam bentrokan tersebut. Satu warga meninggal dunia, dua orang mengalami kritis, 37 rumah terbakar akibat bentrokan tersebut. Aksi kekerasan dan bentrokan ini melibatkan kurang lebih 500 orang (Ida dan Dyson, 2015: 35).

Konflik ini berujung pada pengusiran jamaah Syiah di kecamatan tersebut, apalagi ajaran Syiah merupakan ajaran yang sesat menurut fatwa MUI Jatim. Fatwa ini sesuai dengan Keputusan No 01/SKFMUI/JTM/I/2012 tentang larangan ajaran Syiah ini, dikeluarkan pada 21 Januari 2012. Untuk memperkuat fatwa MUI Jawa Timur, Gubernur Jawa Timur juga mengeluarkan Surat Keputusan (SK) nomor 55 Tahun 2012 tentang Pembinaan Kegiatan Keagamaan dan Pengawasan Aliran sesat di Jatim.

Pasca konflik tahun 2012, warga pengikut Syiah di Sampang menjadi warga minoritas dengan diskriminasi hak-hak mereka sebagai warga negara.
Misalnya, keluarga-keluarga Syiah yang melahirkan tidak bisa mengurus akte kelahiran. Begitu juga yang sudah menginjak usia 17 tahun tidak bisa memperoleh KTP. Bahkan kehidupan mereka menjadi semakin terpuruk. Anak-anak mereka juga dilarang untuk sekolah. Akhirnya, di antara warga Syiah sendiri saling mengumpulkan uang untuk biaya pendidikan anak-anak warga Syiah lainnya. Mereka patungan agar anak-anak mereka bisa bersekolah dan memperoleh hak pendidikan (Ida dan Dyson, 2015: 45).

\section{Kesimpulan}

Akar konflik Sunni dan Syiah dilandasi motif persaingan kekuasaan, bukan motif agama. Konflik dimulai dari suksesi kepemimpinan pasca meninggalnya Nabi Saw., pengangkatan Abu Bakar menjadi pengganti Nabi Saw. dan reaksi Fatimah Az-Zahra yang enggan membaiat Abu Bakar sebagai pemimpin umat Islam penerus Nabi Saw. Pada era modern, apabila ditelusuri sumber utama konflik di Timur Tengah bukanlah sekedar sentimen agama, melainkan faktor geografi politik, yaitu berkaitan dengan perbatasan, sumber daya alam berupa minyak dan air.

Konflik yang tidak terlepas dari sentimen Sunni-Syiah di Timur Tengah, antara lain: konflik Sunni Syiah dalam Perang Teluk, penyerangan terhadap peringatan hari Asyura (Karbala Massacre), konflik Sunni Syiah di Suriah dan Lebanon, dan konflik Sunni Syiah pada Perang Sipil Yaman. Mayoritas Muslim Indonesia adalah penganut Sunni. Sejumlah kecil penganut Syiah hidup di tengah kaum mayoritas tersebut. Pasca Revolusi Iran, Syiah menjadi bahan pemikiran yang sangat populer di Indonesia, khususnya di kalangan intelektual. Fenomena gerakan anti Syiah merupakan dampak dari situasi geopolitik di antara bangsa-bangsa Arab di Timur Tengah. Dampak dari gerakan tersebut adalah terjadinya konflik Sunni Syiah di Indonesia, yang meliputi: penyerangan terhadap Pondok Pesantren berhaluan Syiah, pembubaran terhadap peringatan 
tradisi Asyura, pembubaran terhadap peringatan hari lahir Fatimah Az-Zahra, pelarangan terhadap Yayasan Rausyan Fikr di Yogyakarta, dan penyerangan terhadap warga Syiah di Madura.

\section{Daftar Pustaka}

Affan, Mohammad dkk. 2014. Bara di Pulau Garam; Mengurai Konflik Syiah-Sunni di Sampang Madura. Yogyakarta: Suka-Press.

Al-Mandari, Syafinuddin. 2015. “Ormas Islam di Tengah Tantangan Komunikasi Penganut Syiah dan Sunni dalam Diskursus Gerakan Islam Moderat", Jurnal Maarif. Vol. 10, No. 2.

Anderson, Ewan W. 2000. The Middle East - Geography \& Geopolitics. London: Roudledge.

An-Najah; FPI Makasar Bubarkan Peringatan Asyura; https://www.annajah.net/fpi-makasar-bubarkanperingatan-asyura-yang-dihadirijalaludin-rahmat/; diakses pada tanggal 26 September 2019.

Annas Indonesia; Iftitah dan Sejarah Aliansi Nasional Anti Syiah; http://www.annasindonesia.com/pro fil/iftitah-dan-sejarah-aliansinasional-anti-syiah; diakses pada tanggal 10 September 2019.

Armstrong, Karen. 2007. Perang Suci: dari Perang Salib hingga Perang Teluk. Jakarta: Serambi.

As-Sirjani, Raghib. 2015. The Harmony of Humanity, Teori Baru Pergaulan Antarbangsa Berdasarkan Kesamaan Manusia. Jakarta: Pustaka Al-Kautsar.

Baharun, Mohammad. 2013. Mengenal dan Mewaspadai Penyimpangan Syiah di Indonesia. Jakarta: AlQalam.

BBC. 2006. Lebanon Crisis Explained; http://www.bbc.co.uk/indonesian/in depth/story/2006/11/061123_lebano ncrisisexplained.shtml; diakses pada tanggal 29 Agustus 2019.
BBC. 2013. Forum Syiah; https://www.bbc.com/indonesia/for um/2013/11/131115_forum_syiah; diakses pada tanggal 26 September 2019.

Detik. Penyerangan Jamaah Syiah; https://news.detik.com/berita-jawatimur/d-1802832/penyeranganjamaah-syiah-cmars-pemerintahgagal-melindungi-warganya; diakses pada tanggal 1 Oktober 2019.

Gyorgy, Andrew. 1944. Geopolitics: The New German Science. Berkeley: University of California Press.

Ida, Rachmah dan Dyson, Laurentius. "Konflik Sunni-Syiah dan dampaknya terhadap komunikasi intra-religius pada komunitas di Sampang-Madura". Jurnal Masyarakat, Kebudayaan dan Politik Vol. 28. No. 1. tahun 2015.

Indriana, Nilna. Pemetaan Konflik di Timur Tengah (Tinjauan Geografi Politik), An-Nas: Jurnal Humaniora, Vol. 1, No. 1, Februari 2017.

Kiblat; 2013; Kronologi Bentrok Umat Islam Jember Vs Syiah; https://www.kiblat.net/2013/09/13/k ronologi-bentrok-umat-islamjember-vs-syiah/; diakses pada tanggal 20 September 2019.

Kiblat; 2016; Acara Tokoh Syiah di Pekanbaru Dibubarkan Warga dan Aparat; https://www.kiblat.net/2016/04/02/a cara-tokoh-syiah-di-pekanbarudibubarkan-warga-dan-aparat/; diakses pada tanggal 29 September 2019.

Long, David E. and Reich, Bernard. 1980. The Government and Politics of the Middle East and North Africa. Colorado: Westview Press.

Merdeka; Gara-gara Suriah, Sunni Syiah di Lebanon Memanas; https://www.merdeka.com/khas/gar a-gara-suriah-syiah-sunni-di- 
Lebanon-memanas-konflik-sunnisyiah-3.html; diakses pada tanggal 29 Agustus 2019.

Muwahidah, Siti Sarah. "Melampaui Batas Identitas Sektarian Sunni-Syiah", Jurnal Maarif. Vol. 10, No. 2. Desember 2015.

Nasr, Sayyed Hossein. The Heart of Islam: Pesan-Pesan Universal Islam untuk Kemanusiaan. Bandung: Mizan. 2003.

Okezone; 2013; Bentrok Warga dengan Penganut Syiah; https://news.okezone.com/read/201 3/09/11/521/864633/bentrok-wargadengan-penganut-syiah-satu-orangtewas; diakses pada tanggal 20 September 2019.

Okezone; 2016; Kronologi Pembubaran Pengajian IWOC di Pasuruan; https://news.okezone.com/read/201 6/04/01/519/1351738/kronologipembubaran-pengajian-iwoc-dipasuruan; diakses pada tanggal 29 September 2019.

Pojok Satu; 2018; Tradisi Syiah di Indonesia; https://pojoksatu.id/lipsus/2018/06/ 08/9-tradisi-syiah-indonesia-nomor8-paling-sering-kamu-kerjakanlho/; diakses pada tanggal 5 September 2019.

Putra, Ahmad Roni Adi; Memandang Perspektif Gerakan Revolusi Syiah; https://www.kompasiana.com/ahma droniadiputra8149/5bb34694677ffb 78844e7597/memandangperspektif-gerakan-revolusi-syi-ah; diakses pada tanggal 15 September 2019.

Rais, Ahmad Imam Mujadid. Syiah, Sektarianime, dan Geopolitik: Suatu Pengantar, Jurnal Maarif. Vol. 10, No. 2. Desember 2015.

Rakhmat, Jalaluddin. Akar Ideologis Konflik Sunni-Syiah. Jurnal Maarif. Vol. 10, No. 2. Desember 2015.
Rini, Endang Agus Setya; Keterkaitan Konflik Sunni-Syiah Dalam Konflik Suriah Pada Masa Bashar Al-Assad (2011-2016);

journal.student.uny.ac.id , ojs , index.php > risalah , article , download; diakses pada tanggal 15 Agustus 2019.

Sahide, Ahmad. "Konflik Syi'ah-Sunni Pasca-The Arab Spring", Kawistara, Vol. 3, No. 3, Desember 2013.

Shah, Muhamad Aunul Abied. Antara Toleransi dan Intoleransi, dari SubOrdinasi menuju Ko-Eksistensi dalam Relasi Sunni-Syiah Kontemporer, Jurnal Maarif. Vol. 10, No. 2. Desember 2015.

Shaleh, Muhsin Muhammad. 2001. Palestina: Sejarah, Perkembangan, dan Konspirasi. Jakarta: Gema Insani Press.

Sultriana dan Mustahyun. Dinamika Konflik Sunni-Syiah di Indonesia Prespektif Kuasa Michel Foucault. PALITA: Journal of Social-Religion Research, Vol.2, No.2. Oktober 2017.

Tempo; Kelompok Syiah di Yogya Diancam Diserang; https://nasional.tempo.co/read/5317 05/kelompok-syiah-di-yogyadiancam-diserang; diakses pada tanggal 29 September 2019.

Tempo; Kenapa Yaman Dilanda Perang; https://dunia.tempo.co/read/114212 4/kenapa-yaman-dilandaperang?page_num $=2$; diakses pada tanggal 29 Agustus 2019.

Tempo; Markas Syiah di Jalan Kaliurang Diserbu Massa; https://nasional.tempo.co/read/7124 42/markas-syiah-di-jalan-kaliurangdiserbu-massamengapa/full\&view=ok; diakses pada tanggal 29 September 2019.

Tirto; Penolakan Peringatan Asyura di Bandung; https://tirto.id/penolakanperingatan-asyura-di-bandung- 
c1SR; diakses pada tanggal 26 September 2019.

Tribun News; 2011; Inilah Kronologi Penyerangan Pondok Pesantren Yapi;

https://www.tribunnews.com/region al/2011/02/15/inilah-kronologispenyerangan-pondok-pesantrenyapi; diakses pada tanggal 15 September 2019.
Tribunnews Aceh; 2018; Inilah Lima Fakta di Balik Perang Suriah yang Mengerikan;

https://aceh.tribunnews.com/2018/0 4/14/inilah-5-fakta-di-balik-perangsuriah-yang-mengerikan?page $=2$; diakses pada tanggal 29 Agustus 2019.

15 Widyadara, Resta Tri. "Konflik SunniSyiah di Indonesia". Jurnal Religi. Vol. XI, No. 2, Juli 2015. 